\title{
エレクトロスピニング 機能性高分子ナノファイバーの創製—
}

もっとも簡便なナノテクノロジーのひとつであるエレクトロスピニ ングに注目が集まっている。真空装置や加熱装置が不要で，常温大気 圧下で容易にナノファイバーや不織布が得られることから, その汎用 性はきわめて高い。エレクトロスピニングによる機能性高分子のナノ ファイバー化について概説するとともに，今後を展望する。

奥 崎 秀 典

\section{1.はじめに}

「エレクトロスピニング」とは, 高分子溶液または融液に 高電圧を印加することで電気的に㵶維を紡糸する方法であ り，その発見は 1930 年代にさかのぼる11。真空装置や加熱 装置が不要で, 常温大気圧下で容易にナノ〜マイクロメー トルオーダーの繊維や哌織布が得られることからその汎用 性はきわめて高く，あっとあ簡便なナノテクノロジーのひ とつとして注目を集めている2。高分子溶液を入れたシリ ンジの針先に電圧を印加した際に静電的な引力が溶液の表 面張力を超えると, Taylor cone と呼ばれる円錐状に变形 し，その先端が引き伸ばされ霧状のジェットを形成する （図 1）。帯電した溶液の静電反発により液滴は微細化し, その大きな表面積のために溶媒が瞬時に蒸発する。結果と して, ターゲット電極上には高分子固体のみが不織布状に 付着する。

1970 年代以降, アクリル樹脂3)やポリエチレン, ポリプ ロピレンなどの汎用高分子4へと応用され, 溶液の粘度や 雾囲気，流速，印加電圧などが得られた繊維のモルホロ ジーや結晶構造などに与える影響について詳細に検討され ている。1990年代に入ると，エレクトロスピニングにお けるナノファイバー形成のメカニズムや応用に関する研究 が Reneker らのグループを中心に行われ, 液晶性高分 子5), $\mathrm{DNA}^{6)}$, タンパク質7), 導電性高分子8》,9)など機能性高 分子材料について検討されている。また, エレクトロスピ

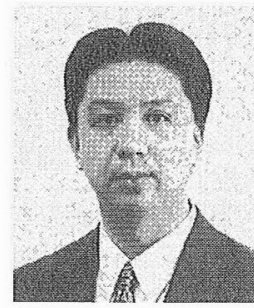

OKUZAKI, Hidenori 山梨大学大学院医学 工学総合研究部 (400-8511 甲府市武田 44-37) 助教授, 博士 (理学).1994年 北海 道大学大学院理学研究科博士課程修了. 専門 は機能性高分子。

Nanofibers of Functional Polymers Fabricated by Electrospinning
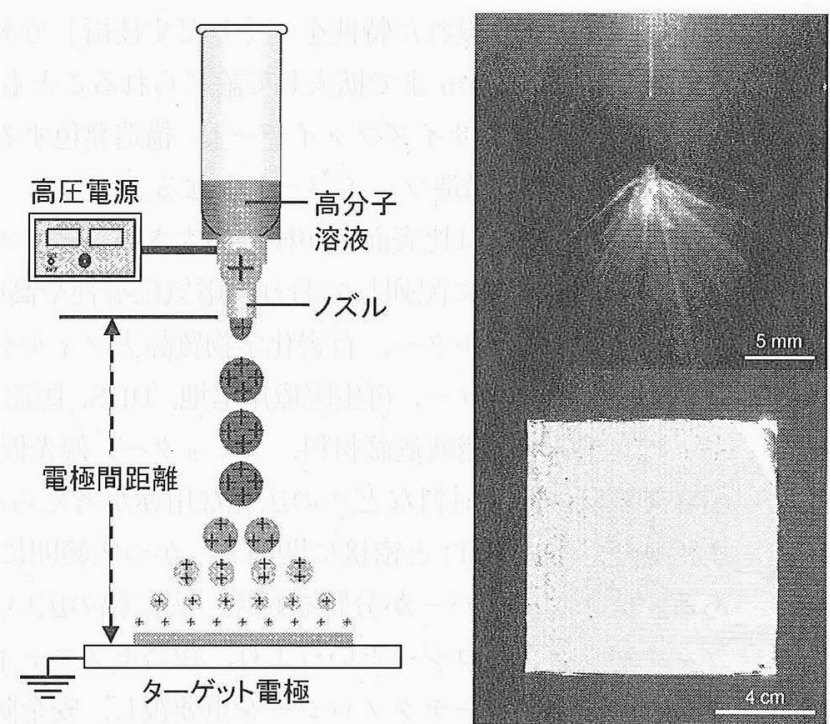

図 1 一般的なエレクトロスピニング装置の模式図（左） と, 高分子溶液に電圧印加したときに形成される ジェット（右上）およびターゲット電極上に不織布状 に付着したナノファイバー（右下）

ニングにより作製した不織布の非常に大きな表面積を利用 した触媒や分離膜，センサー10)などへの応用に関する研究 が盛んに行われている。

本稿では，エレクトロスピニングを用いた生分解性高分 子および導電性高分子のナノファイバー化について，筆者 らの研究を交えながら概説する。

\section{2. ポリ乳酸ナノファイバー}

ポリ乳酸，ポリグリコール酸，ポリ ( -カプロラククン) に代表される生分解性高分子は, グリーンプラとして種々 の生活資材や医療材料に応用されている11)。なかでもポリ 乳酸は, 室温以上のガラス転移点と $170^{\circ} \mathrm{C}$ 以上の融点をも つ結晶性の熱可塑性高分子であり ${ }^{12)}$, エレクトロスピニン 


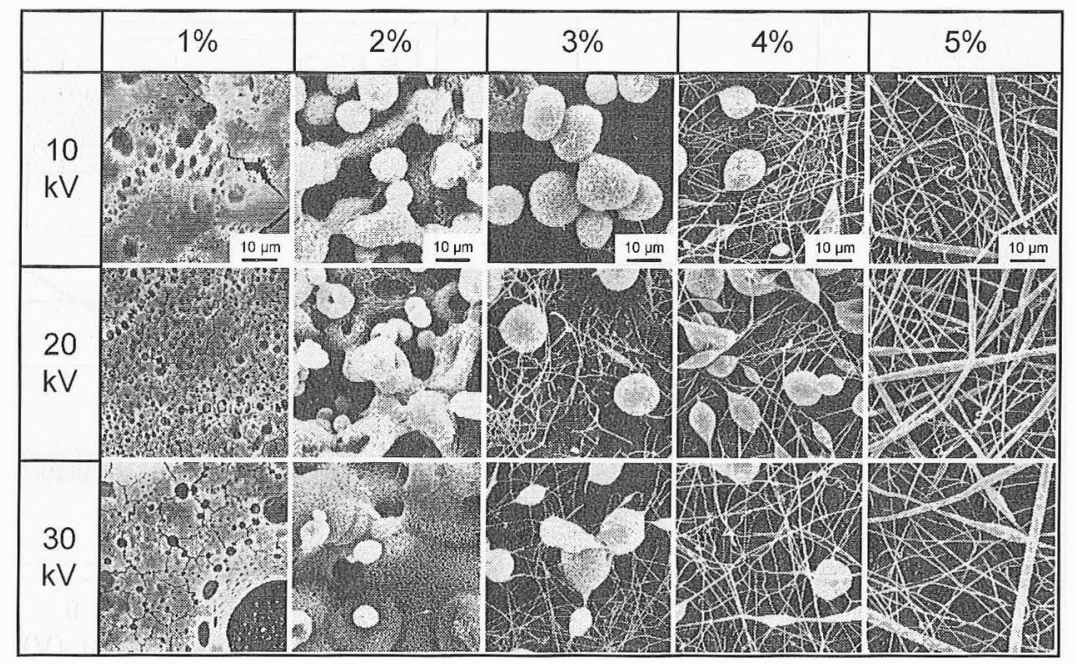

図 2 種々の濃度および印加電圧でポリ乳酸/クロロホルム溶液をエレクトロスピニングした試料の SEM 写真
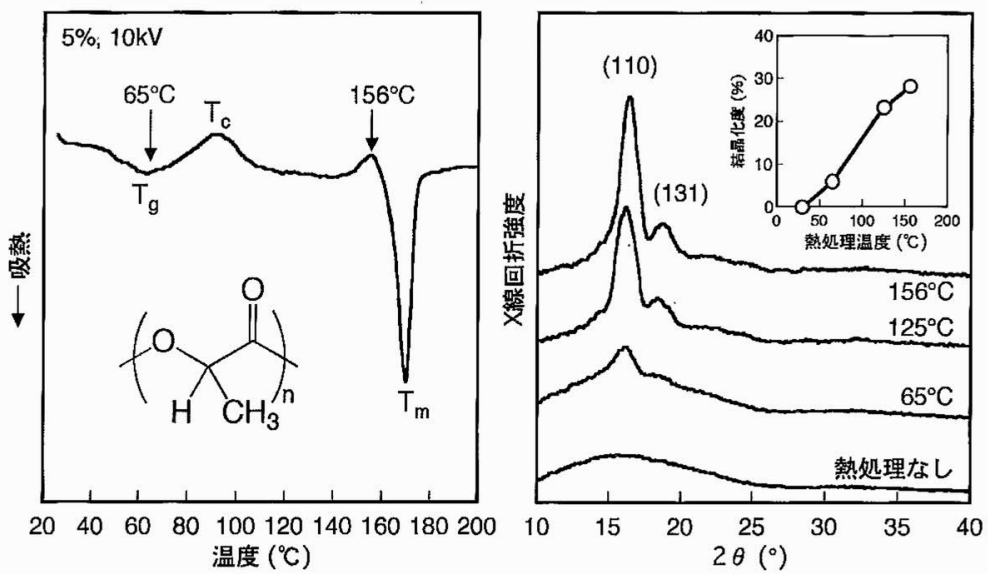

図 3 エレクトロスピニングにより作製したポリ乳酸ナノファイバーのDSC曲線（左）と，種々の温度で熱処理したときの広角X 線回折パターンおよび結晶化度の变化（右）

グについて多くの研究例がある13)。

ポリ乳酸ペレット（ラクティ，(株)島津製作所製）をク ロロホルムに溶解し，印加電圧および溶液濃度を变化させ てェレクトロスピニングを行ったときのSEM 写真を図 2 に示す。モルホロジーは印加電圧よりあ濃度に大きく依存 し，1\%ではマット状，2\%では粒状，3～4\%では粒子と繊 維の混在状態，5\%では繊維のみを生成した。その際，直径 5〜15 $\mu \mathrm{m}$ の粒子が棈円形に変形し, その両末端から直径 300〜500 nmのファイバーが延びている様子がわかる。

濃度 $5 \%$, 印加電圧 $10 \mathrm{kV}$ のエレクトロスピニングで得 られたポリ乳酸ナノファイバーは, 昇温過程でガラス転移 温度 $\left(T_{\mathrm{g}}\right)$, 結晶化温度 $\left(T_{\mathrm{c}}\right)$ そして融点 $\left(T_{\mathrm{m}}\right)$ を示し, 広角 $\mathrm{X}$ 線回折より非晶質であった（図 3)。これは, エレクトロ スピニングの過程で急激な脱溶媒が起こり, 結晶化が阻害 されたためと考えられる。 $T_{\mathrm{c}}$ 以上で熱処理することによ り (110), (131) 面加らの回折ピークが明確に現れ, 結晶化 度は大きく増加した。その際, 繊維の形状を保持しておう, 直径も熱処理前後でほとんど変化しないことがわかってい $3^{14)}$ 。

一般に，生分解性高分子は再生医療において細胞培養の
足場としてはたらくが，細胞の接着性や移動性も重要な要 素である。エレクトロスピニングにより得られる直径ナノ 〜マイクロメートルのファイバーからなる不織布は, 大き な表面積を有するために細胞の接着性が向上するだけでな く, マイクロメートルサイズの空隙を細胞が内部まで移動 して増殖するため, 細胞が足場全体に広がる利点があ る $^{15)}$ 。らに不織布内部ではナノファイバーが三次元的に からみ合っており, 構造的にむ力学的にあ生体内の細胞外 マトリックスに類似している ${ }^{16}$ 。 一方, 生体内に移植後, これら足場は組織の再生とともに適度な速度で分解・吸収 されることが望ましい。

一般に，ポリ乳酸の生分解挙動には，その高分子の形状 や表面積, 結晶化度などの高次構造, 機械的特性などが大 きく関与している ${ }^{17)}$ c エレクトロスピニングと熱㚭理によ りモルホロジーと結晶化度を制御できることから，さまざ まな生分解特性を示すポリ乳酸の作製が可能である。細胞 培養のほか, 人工皮膚や人工血管 ${ }^{18)}$, 薬物徐放システム ${ }^{19)}$ などへの応用が検討されている。 

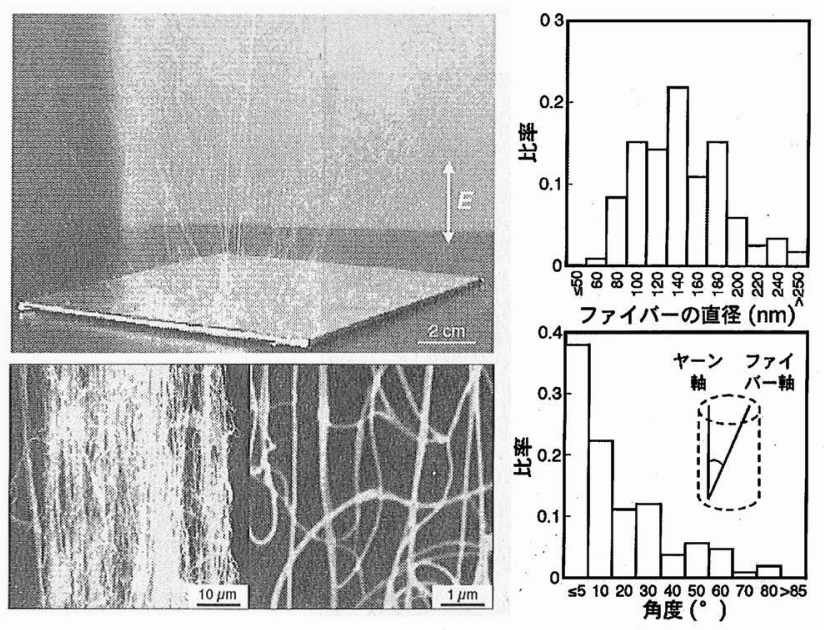

図 $4 \mathrm{PPV}$ 前駆体の水/メ夕ノール溶液をエレクトロスピニ ングすることにより自発的に形成されるナノファイ バーヤーン (右上) 之, 熱処理により得られた PPV ナノファイバーヤーン（左下）の直径分布（右上）お よび配向分布（右下）

\section{3. 導電性高分子ナノファイバー}

有機半導体や導電性高分子は, 安価で軽量, フレキシブ ルなプラスチックエレクトロニクスにおけるキーマテリア ルである ${ }^{20)}$ ，導電性高分子のファイバー化 ${ }^{21)}$ は，微細配線 やケーブル，ヒニーズ，アンテナやコイルのみならず，電 磁波遮蔽材料や帯電防止衣服など機能性不織布への応用が 期待される。筆者らは, 代表的な有機半導体であるポリ（ $p$ フェニレンビニレン) (PPV)のナノファイバー化を試み $た^{22)}$ 。

一般に, PPV は不溶不融で加工性が低く, フィルムや䋊 維の作製には溶媒に可溶な前駆体が用いられる ${ }^{23)}$ 。こ で，前駆体溶液にエレクトロスピニングを適用し，熱変換 することで PPVナノファイバーを作製した。まず，PPV 前駆体であるポリ（ $p$-キシレンテトラヒドロチオフェニウ ムクロライド）の $0.25 \%$ 水溶液に $30 \mathrm{kV}$ まで電圧を印加 したが，安定かつ連続的なジェットは形成されず，タ一 ゲット電極上にファイバーは得られなかった。これは，高 分子電解質である前駆体が強く水を保持するととむに，水 溶液の高い表面張力之粘性に起因すると考えられる。そこ でメタノールを加えたところ，メタノール濃度 40〜90\% で連続的なジェットが形成された。興味深いことに，夕一 ゲット電極上に無数のナノファイバーが生成し，さらにそ れらがからみ合いながら自発的にヤーンを形成することが わかった (図 4)。これに対し，メタノールが 40\%以下では 連続的なジェットは形成されず，逆に 90\%以上では脱溶 媒が不完全になり，液体のみが電極上に付着した。

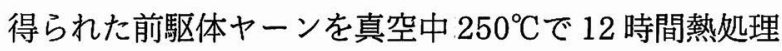
することにより，テトラヒドロチオフェンと塩化水素が脱 離し, 前駆体のモルホロジーを保ったままPPVに変換さ れる。ヤーンの太さは約 $100 \mu \mathrm{m}$ であり, 直径 50〜200 $\mathrm{nm}$ の PPVナノファイバーから形成されていることがわ

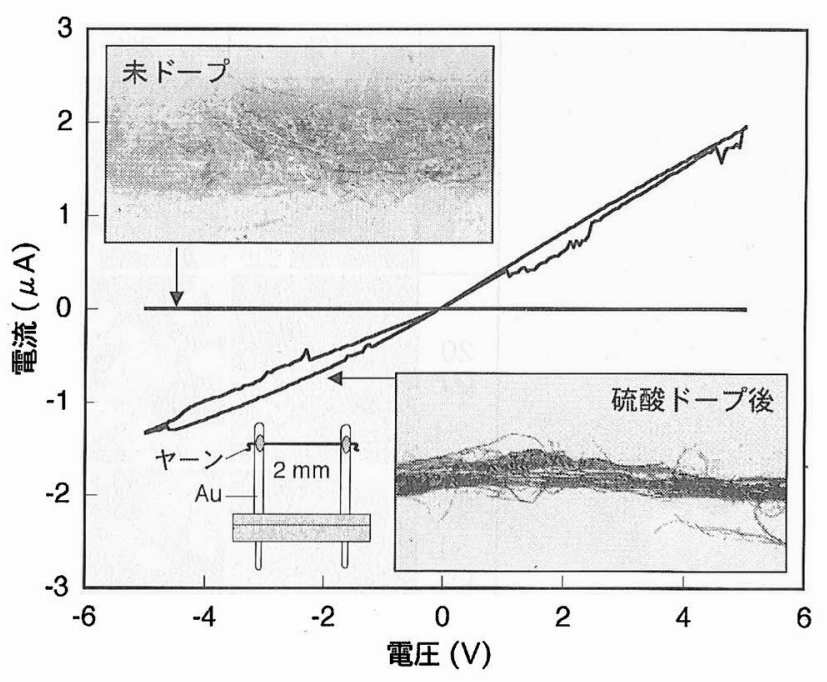

図 $5 \mathrm{PPV}$ ナフファイバーヤーンに硫酸をドープしたときの 電流電圧特性の変化

かった。さらに, PPVナノファイバーはヤーンの軸に沿っ て並んでおり，よりや延伸などの後処理をしなくてむナ， ファイバーの配向や集合状態を制御できることが明らかに なった。得られたPPV は半導体であり，適当なドーパン トで処理することにより電導性を示す ${ }^{24)}$ 。図 5 に示すよう に，褐色の中性状態ではほとんど電流が流れないのに対 し，黒色のドープ状態では電導性を示した（図 5)。導電性 高分子ナノファイバーの大きな表面積を利用した高感度化 学センサーや高速で駆動するアクチュエーターなどへの応 用が期待できる。

\section{4. さらなる高機能化に向けて}

ナノファイバーのさらなる高機能化のためのアプローチ として，材料の複合化とスピニングの工夫があげられる。 Ko らはポリアクリロニトリルとカーボンナノチューブの 混合物をエレクトロスピニングするこよで, カーボンナ， チューブが繊維軸方向に配向した高強度ナノコンポジット を作製している25) カーボンナノファイバーをエレクトロスピニングで作製 し，その表面からカーボンナノチューブを成長させた階層 構造を実現している26)。これらは，燃料電池や酸化還元電 極，ナノエレクトロニクスへの応用が期待されている。

一方, エレクトロスピニングの装置や手法を工夫するこ とで，高機能化を図ることも可能である。Greiner,や Xia らは，ノズルの内側にキャピラリーを挿入することで，コ ア・シェル型ナノファイバー27)や中空ナノファイバー（ナ /チューブ) ${ }^{28)}$ を作製している。また，平行に配置された 2 つの電極をターゲットに用いることで, ファイバーの配向 制御が可能である ${ }^{29)}$ ○これに対し，谷岡らは直径分布の狭 い均一なナノファイバーからなる不織布を作製し，これが ある波長の可視光を強く散乱する構造発色特性を示すこと 
を見いだしている30)。また最近では，生分解性高分子を直 接皮膚にエレクトロスピニングする研究む報告されてい $ろ^{31)}$ ，移植部分や患部に直接エレクトロスピニングするこ とで，テーラーメイドの人工皮膚やコーティングが可能で ある ${ }^{32)}$ 。さらに，トップダウン的手法であるエレクトロス ピニングと，ボトムアップ的手法である自己組織化を組合 せることにより，超分子ナノファイバーの作製む試みられ ている ${ }^{33)}$ c

\section{5. おわりに}

このように，エレクトロスピンングはまだ完成した技術 とはいえず，また最近の進歩も著しいことから今後さまざ まな分野に掞いて急速な用途の広がりが予想される。エレ クトロスピニングの装置が国内メーカーから市販されてい ることもあり ${ }^{34), 35), ~}$ 研究はさらに加速するであろう。今後 の展開が期待される。

\section{文献}

1) A. Formhals: U.S. Patent, No. 1975504 (1934)

2) 高橋卓己，奥崎秀典：工業材料， 51, 34 (2003)

3) P. K. Baumgarten: J. Colloid Interf. Sci., 36, 71 (1971)

4) L. Larrondo, R. St. J. Manley: J. Polym. Sci. Polym. Phys., 19, 909 (1981)

5) G. Srinivasan, D. H. Reneker: Polym. Int., 36, 195 (1995)

6) X. Fang, D. H. Reneker: J. Macromol. Sci. Phys., 36, 169 (1997)

7) J.A. Matthews, G. E. Wnek, D. G. Simpson, G. L. Bowlin: Biomacromolecules, 3, 232 (2002)

8) D. H. Reneker, I. Chun: Nanotechnology, 7, 216 (1996)

9) A. G. MacDiarmid, W. E. Jones, Jr., I. D. Norris, J. Gao, A. T. Johnson, Jr., N. J. Pinto, J. Hone, B. Han, F. K. Ko, H. Okuzaki, M. Llaguno: Synth. Met., 119, 27 (2001)

10) X. Wang, C. Drew, S.-H. Lee, K. Senecal, J. Kumar, L. Samuelson: Nano Lett., 2, 1273 (2002)
11）白石信夫, 谷 吉樹, 工藤謙一, 福田和彦：バイオプラスチッ クのすべて, 工業調査会, 1992

12) H. Okuzaki, I. Kubota, T. Kunugi: J. Polym. Sci., Part B: Polym. Phys., 37, 991 (1999)

13）奥崎秀典，石原将義，桑原哲夫，鈴木保任：高分子学会予稿 集, 51, $1102(2002)$

14）高橋卓已，奥崎秀典： $W E B ~ J ., 62,15$ (2004)

15) H. Yoshimoto, Y. M. Shin, H. Terai, J. P. Vacanti: Biomaterials, 24, 2077 (2003)

16) W.-J. Li, R. Tuli, C. Okafor, A. Derfoul, K. G. Danielson, D. J. Hall, R. S. Tuan: Biomaterials, 26, 599 (2005)

17）望月政嗣：高分子学会講演会「グリーンプラ（生分解性ポリ マー）の最近の進歩と応用」講演要旨集, p. 1 (1997)

18) S. Kidoaki, I. K. Kwon, T. Matsuda: Biomaterials, 26, 37 (2005)

19) X. Zong, K. Kim, D. Fang, S. Ran, B. S. Hsiao, B. Chu: Polymer, 43, 4403 (2002)

20) 奥崎秀典：高分子, 51, 25 (2002)

21) H. Okuzaki, M. Ishihara: Macromol. Rapid Commun., 24, 261 (2003)

22）高橋卓己, 宮嶋尚哉, 鈴木保任, 桑原哲夫, 奥崎秀典：高分子 学会予稿集, 53, 1569 (2004)

23) H. Okuzaki, N. Ikeda, I. Kubota, T. Kunugi: Macromolecules, 32, 5606 (1999)

24) H. Okuzaki, N. Ikeda, I. Kubota, T. Takahashi: Synth. Met., 153,165 (2005)

25) F. Ko, Y. Gogotsi, A. Ali, N. Naguib, H. Ye, G. Yang, C. Li, P. Willis: Adv. Mater., 15, 1161 (2003)

26) H. Hou, D. H. Reneker: Adv. Mater., 16, 69 (2004)

27) Z. Sun, E. Zussman, A. L. Yarin, J. H. Wendorff, A. Greiner: Adv. Mater., 15, 1929 (2003)

28) D. Li, Y. Xia: Nano Lett., 4, 933 (2004)

29) D. Li, Y. Wang, Y. Xia: Adv. Mater., 16, 361 (2004)

30）谷岡明彦, 諸田謙治, 松本英俊, 皆川美江, 山形 豊, 井上浩 三：繊維学会予稿集, 59, 82 (2004)

31) E.-R. Kenawy, J. M. Layman, J. R. Watkins, G. L. Bowlin, J. A. Matthews, D. G. Simpson, G. E. Wnek: Biomaterials, 24, 907 (2003)

32) D. Adam: Nature, 411, 236 (2001)

33）高橋卓己, 石原将義, 桑原哲夫, 鈴木保任, 宮嶋尚哉, 奥崎秀 典：高分子学会予稿集，52, $343(2003)$

34) http://www.fuence.co.jp/technology/tec01.html

35) http://www.keskato.co.jp/neu.html 